\title{
Customers' Perception of Business Model Innovation in Social Enterprises in Mexico
}

\author{
Judith Cavazos-Arroyo ${ }^{*}$, Rogelio Puente-Díaz ${ }^{2}$
}

\begin{abstract}
Social enterprises need to identify an innovative and differentiated business model to more efficiently meet the needs of their clients and survive in the long term. However, research on customer perception of this innovation is scant. Therefore, the objective of this research was to explore the effect of socially responsible consumption on the business model innovation perceived by clients of social enterprises in the service sector and its effect on satisfaction and loyalty. A quantitative cross-sectional study was conducted with 400 customers of social enterprises in the services sector in Mexico. Results showed that socially responsible consumption had a positive influence of perceived business model innovation. Perceived business model innovation had a direct, positive influence on customer satisfaction and an indirect positive influence on loyalty. The implications of the results were discussed.
\end{abstract}

Keywords: Business model innovation; socially responsible consumption; social enterprise; consumer

Submitted: July $15^{\text {th }}, 2021 /$ Approved: August $20^{\text {th }}, 2021$

\section{Introduction}

More consumers with different characteristics and socioeconomic levels are choosing responsible consumption options (deKlerk, Kearns \& Redwood, 2019). This implies that they make purchasing decisions based, in part, on pro-social values when consuming products and services (Golob et al., 2019). For this reason, organizations with explicit corporate social responsibility efforts and social enterprises need to strategically configure their business model to generate value and obtain a competitive advantage. Innovation is one of the significant determinants of value creation (Austin \& Seitanidi, 2012). For instance, it can arise in the product or service (Lusch \& Nambisan, 2015), in the strategies (Pitelis, 2009) or even in the business model (Berends, Smits, Reymen, \& Podoynitsyna, 2016). The topic of business model innovation (BMI) has attracted the attention of commercial and social enterprises, as well as the academic domain (Clauss, Kesting, \& Naskrent, 2018; Wang \& Zhou, 2020). The present article examines $\mathrm{BMI}$, from the perception of customers, in social enterprises that act as agents of change and that operate in the service sector in an emerging country. Conducting empirical research is important because on the one hand, the literature indicates that this type of research is scarce (Clauss et al., 2018; Lee, 2015; Olofsson, Hoveskog, \& Halila, 2018). On the other hand, the empirical evidence reflects that many social companies struggle to identify a sufficiently differentiated business model to solve social problems and survive in the long term (Santos, Pache, \& Birkholz, 2015; Zainol et al., 2019). Consequently, more empirical efforts are needed.

In addition, some business scholars have recommended developing the external perspective of the business innovation model process, which entails assessing the perspective of customers (Chesbrough et al., 2018; Foss \& Saebi, 2017). Thus, this study focuses on the vision of social business customers with respect to business model innovation and its effect on relevant variables for customer retention. We delineate the scope of our study to the service sector, because service business models compared to product business models involve a higher degree of customer interactions. Consequently, the purpose of this investigation is to explore the effect of socially responsible consumption on customers' perceived business model innovativeness and its effect on satisfaction and loyalty. This paper contributes to the literature on business model innovation in social enterprises from the perspective of current customers.

\section{Literature Review}

A business model begins as an idea that is designed and then implemented; innovation in a business model could arise when the business model is itself an innovation (George \& Bock, 2011). Business model innovation is defined as "the discovery of a fundamentally different business model in an existing business" (Markides, 2006, p. 20). An innovative business model could be used to improve competitive position (Bereznoi, 2015), business performance (Karimi \& Walter, 2016) and attract customers (Clauss et al., 2018). It is a complex, collective, cyclical and interactive process that contributes to the creation and delivery of customer value, while the organization captures some of the value created (Berends et al., 2016; Olofsson et al., 2018).

In the case of social enterprises, BMI may be key to establish an innovative management and build a sustainable hybrid business that leads to efficient performance and growth, while complying with environmental and social criteria (Wang \& Zhou, 2020). This means that the social enterprise will rely on obtaining economic resources to achieve social and/or environmental goals that could become competitive advantages (Battilana \& Lee, 2014), resulting in the desired change in behavior. This focus on business model innovation often leads to positive results, as seen in the positive relationship between perceptions

(1) Department of Business and Economics sciences, Universidad Popular Autónoma del Estado de Puebla, Puebla, Mexico (2) Department of Business and Economics, Universidad Anahuac Mexico Norte, Huixquilucan, Estado de Mexico, Mexico

${ }^{*}$ Corresponding author: judith.cavazos@upaep.mx

ISSN: 0718-2724. (http://jotmi.org)

Journal of Technology Management \& Innovation (c) Universidad Alberto Hurtado, Facultad de Economía y Negocios. 
of BMI and customer value (Clauss et al., 2018). Thus, it is possible to posit that the BMI is formed by the following three components that help an organization configure or reconfigure its business model (Osterwalder \& Pigneur, 2010): Innovation in the creation of value, value propositions and the capture of value (Clauss, 2017; Nielsen \& Bukh, 2011).

Anderson, Narus, and Van Rossum (2006, p. 24) define value as "the worth in monetary terms of the technical, economic, service, and social benefits a customer receives in exchange for the price it pays for a market offering". Business models seek to create value with a focus on the external perspective, mainly customers and their interactions in the configuration of BMI processes (Sjödin et al., 2020). Thus, value creation can be understood as the processes aimed at increasing the generation of value (Chesbrough et al., 2018) based on the company's resources and capabilities (Achtenhagen, Melin, \& Naldi, 2013) and reflected as the experience of the product or service by the customer (Keiningham et al., 2020). Value creation innovativeness is one of the components of the business model innovativeness and it implies investing in new capabilities, new technologies / equipment, new processes and structures, and / or new partnerships with the expectation that the client will appreciate it and will use the product or service more frequently (Clauss, 2017). Social enterprises cannot assume that, solely by their nature, consumers will perceive and appreciate the value of their business model. Therefore, by investing in valuecreating innovation, the hybrid social enterprise wants to improve both its economic performance and obtain a social return on investment (Mook, Chan, \& Kershaw, 2015).

The second dimension of the BMI refers to value proposition innovativeness (Lindič \& Marques da Silva, 2011). It describes how innovative a company's offer is in relation to its competitors (Lindič \& Marques da Silva, 2011). Furthermore, it links value-in-exchange with the value-in-use (Calonius, 2006; Lusch, Vargo \& O'brien, 2007) in the decisive role of customers by favoring buying from the company (Osterwalder \& Pigneur, 2010). For instance, in service innovation, the value proposition is integrated through different practices and resources, and from the interactions of value-in-exchange and value-in use, and between the clients and the context, which jointly determine subjectively perceptions of value (Skalén et al., 2015).

Value capture innovativeness is the last dimension of the BMI (Clauss et al., 2018). From the perspective of value-in-exchange, it implies the way in which the company receives resources in exchange for those provided to another actor, for which the company converts the value into income and distributes the benefits to different partners (Chesbrough et al., 2018; Teece, 2010). Likewise, from the value-in-use, value capture refers to the process of ensuring a part of the value created by another actor at the time of the use of resources (Chesbrough et al., 2018). Therefore, beyond legal contracts, trust between the parties becomes necessary (Reim, Sjödin, \& Parida, 2018). Business model innovation implies the adaptation and the alignment of the three dimensions with each other (Foss \& Saebi, 2018), considering the nature of the interactions with the clients in the conformation of the innovation processes of the business model (Chesbrough et al., 2018).
Corporations are commonly required to be socially responsible; however, individuals also need to be socially responsible. Socially Responsible Consumption (CRS) is a behavior based on prosocial values and moral standards (Golob et al., 2019), and implies that consumers purchase from companies, products and services that they consider not harmful to the environment and that express their current social concerns (Roberts, 1996). Therefore, socially responsible purchasing decisions go beyond socioeconomic levels (Durif et al., 2011, Zhao et al., 2014) and products or services that satisfy a basic need (Crane, 2001; Roberts, 1996), because essentially these consumers believe that they can contribute through their consumption to generate a positive impact on society in general (Petrovskaya \& Haleem, 2020).

A prosocial behavior such as CRS prioritizes purchases from socially responsible companies and social enterprises (Roberts, 1993; Wang \& Zhou, 2020). For instance, it has been found that CRS has been associated with the willingness to support companies that offer cause-related products (Francois-Lecompte \& Roberts, 2006). Also, it is expected that a social enterprise that promotes CRS will seek to satisfy its consumers' search for value through BMI, because it can improve customer value and promote the growth of the company (Wang \& Zhou, 2020). Consequently, it is possible to assume and test the following hypothesis:

H1: Socially Responsible Consumption affects positively customer's perceived business model innovativeness.

In both social and commercial marketing, satisfaction and loyalty are considered key constructs. On the one hand, previous research in the field of social marketing has identified that value creation in social marketing services influences satisfaction and the intention to reuse services (Chell \& Mortimer, 2014; Zainuddin, Tam, \& McCosker, 2016). On the other hand, in the business field, it has been found that the more innovative consumers perceive the business model, the greater the enthusiasm generated, influencing behavioral decisions, the evaluation of the service experienced, customer satisfaction, and loyalty (Clauss et al., 2018).

In general, innovation is an important driver of customer satisfaction and loyalty in the service sector (Gallouj \& Weinstein, 1997). Customer satisfaction refers to "the degree to which an organization's customers continually perceive that their needs are being met by the organization's products and services" (Anderson, Rungtusanatham, \& Schroeder, 1994, p. 480). And service loyalty is a supportive behavior towards the provider (Woratschek, Horbel, \& Popp, 2020) that is understood as a repetitive purchasing behavior to the service provider, with a positive attitude toward it and the consideration of using its services when a need arises (Gremler \& Brown, 1999). Several investigations in the service sector have found that innovation in some aspects of the business model influences customer satisfaction and loyalty (Clauss et al., 2018; YuSheng \& Ibrahim, 2019). Therefore, we propose that:

H2: Customer's perceived business model innovativeness positively affects customer satisfaction.

H3: Customer's perceived business model innovativeness positively affects customer loyalty. 
Theoretical developments and empirical research support the idea that customer satisfaction is an antecedent of loyalty (Caruana, 2002; Gustafsson, Johnson, \& Roos, 2005; Szymanski \& Henard, 2001). Satisfied customers will likely establish an emotional connection with the brand and repeat the service experience (Fraering \& Minor, 2013). The social enterprise is developed around the ideal of uniting social mission with market logic seeking to connect both (Woodside, 2018). Consequently, it has its unique business logic, given that in addition to creating value, it expects its customers to be satisfied with the social mission and with the product and service. In addition, it needs to operate through the effective use of scarce resources and maximize their impact by solving social problems (Ge, Xu, \& Pellegrini, 2019). Consequently, we also incorporate the following hypothesis:

H4: Customer satisfaction positively affects customer loyalty.

\section{Method}

We conducted a quantitative cross-sectional study on clients of social enterprises focused on providing different services in Mexico. Faceto-face surveys to a sample of convenience were applied to 400 clients, although 392 questionnaires were validated for their use. $57.7 \%$ were women and $42.3 \%$ men, with an average age of 35 years. The most used services were health services $64.3 \%$, financial services $14.8 \%$, restaurants $11.5 \%$ and sustainable energy $5.9 \%$.

Measures and Procedure. To measure socially responsible consumption, we used the CSR performance scale with 13 items developed by Webb, Mohr and Harris (2008). In addition, we adapted to social enterprises the three dimensions (Value Creation Innovation, Value proposition innovation, Value capture innovation) of customers' perceived business model innovativeness developed by Clauss et al. (2018). We used the customer satisfaction scale developed by Clauss et al. (2018) and for loyalty, the scale developed by Moisescu (2018). All items were rated on five-point Likert scales: Strongly agree, agree, not certain, disagree, and strongly disagree. Table 1 shows all the items.

Table 1. Scales

CSR performance (CSRP) (Webb, Mohr, \& Harris, 2008)

CSR1. I try to buy from companies that help the needy.

CSR2. I try to buy from companies that hire people with disabilities.

CSR3. I avoid buying products or services from companies that discriminate against minorities.

CSR4. When given a chance to switch to a retailer that supports local schools, I take it.

CSR5. I try to buy from companies that make donations to medical research. CSR6. I make an effort to buy from companies that sponsor food drives.

CSR7. When given a chance to switch to a brand that gives back to the community, I take it.

CSR8. I avoid buying products made using child labor.

CSR9. When given a chance, I switch to brands where a portion of the price is donated to charity.

CSR10. I avoid buying products or services from companies that discriminate against women.

CSR11. When I am shopping, I try to buy from companies that are working to improve conditions for employees in their factories.

CSR12. I try to buy from companies that support victims of natural disasters.

CSR13. I make an effort to buy products and services from companies that pay all of their employees a living wage.
Customers' perceived business model innovativeness (Clauss et al., 2018) Value creation innovation

VCI1. This company is very innovative referring to its employees (e.g., the employees are trained very well, have special skills or set themselves apart in a positive manner from employees of other enterprises, etc.).

VCI2. This company is very innovative referring to its technical equipment (e.g., has a very useful system; has an innovative interior design or has efficient equipment, etc.).

VCI3. This company uses very innovative processes (e.g., has different service options to other companies with which it contends, offers personalized services, etc.)

VCI4. This company puts a lot of emphasis on the usage of partners (e.g., it indicates that it only uses regional, local or vulnerable population providers), it shows the value of a social sector (clients, vulnerable populations that benefit from its efforts).

\section{Value proposition innovation}

VPI1. This company offers services with considerable social innovation (e.g., services are special and directly help a vulnerable sector of society, services are provided in an innovative way, etc.).

ll VPI2. This company uses very innovative sales and advertising channels (e.g., this business offers creative and accessible forms of sale for its customers, it is active in social networks or the service offered relies on a modern website to answer comments and doubts of the customers, etc.)

\section{Value capture innovation}

VCaI1 This company uses very innovative sources of income (e.g., it offers useful supplementary products or services to its customers).

VCaI2. This company offers integrated services (e.g., complementary services, maintenance, etc.).

VCaI3. The price-quantity ratio offered by this company is right

VCaI4. This company applies price differentiation compared to the competition

Satisfaction (Clauss et al., 2018)

CS1. The service provided by this company was of very high quality

CS2. The service provided by this company was reliable.

CS3. On the whole, I was satisfied with my experience with this service

Loyalty (Moisescu, 2018)

LOY1. I consider myself a loyal customer of this company

LOY2. This company is my first choice in its sector

LOY3. I will continue to be a customer of this company

CS4. Overall, my negative experience outweighs my positive experience with this LOY4.In the future I plan to purchase more from this company

company (R)

CS5. In general, I was happy with the service experience
LOY5. I would recommend this company to my friends 
Overall analytical strategy. We used structural equation modelling with Mplus 7.11 treating all variables as latent. In addition, all variables were treated as having a non-normal distribution. We conceptualized customers' perceived BMI as a formative construct and socially responsible consumption, satisfaction and loyalty as reflective constructs. For a model with a formative latent variable to be identified, it needs to predict some other variable. Hence, we only reported the structural model, which includes the measurement model. We reported a combination of absolute and incremental fit index: $\chi^{2}$, Root Mean Square Error of Approximation (RMSEA), Comparative Fit Index (CFI), and Tucker Lewis Index (TLI). We used the cut-off scores of RMSEA $=<.08$ and CFI and TLI $>.90$ as the minimum acceptable levels of model fit (West, Taylor, \& Wu, 2012).

\section{Results}

Results showed an acceptable model fit, $\chi^{2}=651.08, \mathrm{p}<.001(\mathrm{df}=$ 218), $\mathrm{RMSEA}=.072, \mathrm{CFI}=.93$ and TLI $=.92$. Examination of the measurement part of the model revealed that all loadings were significant and in the expected direction, ranging from .27 to .88 . Given these results, we could proceed to interpreting the structural solution.

Examination of the individual parameters revealed a significant influence of socially responsible consumption on perceived business model innovativeness, $\gamma=.69, \mathrm{p}<.001$. Whereas perceived business model innovativeness had a significant influence on customer satisfaction, $\beta=.32, \mathrm{p}<.001$, its influence on loyalty was not significant, $\beta=.04, \mathrm{p}=.27$, respectively. Customer satisfaction had a positive influence on loyalty, $\beta=.85, \mathrm{p}<.001$. Last, perceived business model innovativeness had a significant indirect effect, through satisfaction, on loyalty, .27, $\mathrm{p}<.001$. The squared multiple correlations for the endogenous variables were: customer satisfaction (.10) and loyalty (.74). Figure 1 shows the results of the structural model.

Figure 1. Structural Model

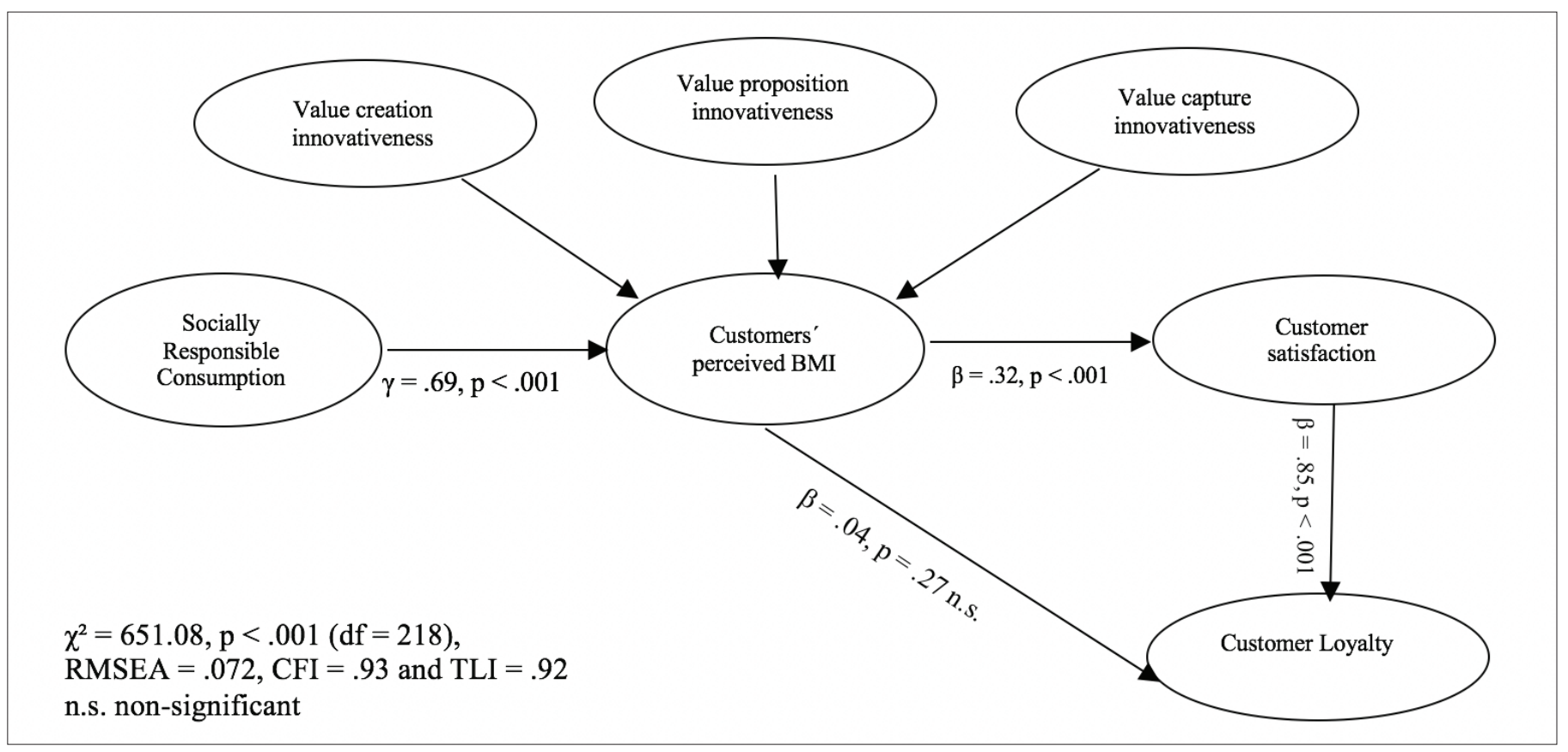

\section{Discussion}

This study explored the effect of socially responsible consumption on customers' perceived business model innovativeness and its effect on satisfaction and loyalty in social enterprises operating in the service sector in Mexico. Our results showed support for the idea that socially responsible consumption influenced customer's perceived business model innovativeness. This result was consistent with previous research (Francois -Lecompte \& Roberts, 2006; Wang \& Zhou, 2020). It is expected that more individuals will seek to consume in a more conscious, responsible and sustainable way (Severo, De Guimarães, \& Dellarmelin, 2021). Consequently, the innovation perceived in the business model is likely to have an impact on competitive advantage of social businesses in the market (Woo, Kim, \& Wang, 2021). That is, social enterprises will have to strive to create, propose and capture value in a meaningful way in their service offered to customers.

We also found that customer's perceived business model innovativeness was positively related to customer satisfaction, which was consistent with previous research conducted in the service sector (Clauss et al., 2018; YuSheng \& Ibrahim, 2019). Conversely, we did not find a significant direct effect of customer's perceived business model innovativeness on loyalty, instead we found an indirect effect through its influence on satisfaction. Previous research identified a significant effect of the perception of the value of the business model on satisfaction (Mahmoud, Jinson, \& Anim, 2018) and on loyalty (Clauss, 
Harengel, \& Hock, 2019); however, the effect of perceived business model innovativeness in social enterprises on loyalty had not been tested through satisfaction; therefore, this is a finding that contributes to the empirical literature. Thus, the results indicated that the BMI consumers' perception on the intangibles and tangibles that facilitate production, delivery and interaction in services had a positive and significant impact on satisfaction; although BMI was not a direct driver of loyalty in the context studied, customer satisfaction performed as a relevant mediator of business innovation strategy, as well as a direct antecedent of customer loyalty, and this is important because loyalty is considered a success factor that contributes to increasing sales (Kim \& Lee, 2020).

In sum, our findings showed that socially responsible consumption was a driver of the positive perception of customers' perceived BMI in social enterprises in the service sector in Mexico. In addition, BMI had a direct effect on customer satisfaction and indirect on loyalty mediated by satisfaction. Innovation in business models in social enterprises concentrates its value mainly in solving social, ethical or environmental problems (Moroz \& Gamble, 2021), and it is a critical aspect for the construction of the value proposition, the differentiation against to competitors, customer retention and social welfare.

\section{Limitations and Future Directions}

This study had several limitations. First, a non-probabilistic sample was used and only social enterprises from the services sector in Mexico were included in the study. Thus, it is recommended to broaden the scope of the BMI research to social enterprises operating in other sectors and in other contexts. It is also recommended to deepen the examination of creation, proposition and capture of value between company and customers, especially when the market logic needs to operate in a more innovative way. Second, even though we wanted to examine business model innovation from the perspective of consumers, we only used self-report data, which limited our ability to understand how perceptions might be related to behavioral variables such as actual sales or repurchases. Future studies could use longitudinal designs to examine how perceived model innovativeness translates into actual sales or repurchases.

\section{Managerial implications}

Our findings have implications for managers of service-focused social enterprises. First, BMI is an important factor to attract and retain customers, thus it is necessary to allocate resources to their development and reconfiguration over time. Second, it is necessary to conceptualize BMI as a mechanism and as a process that actively involves customers' perception of value. This is important because consumers construct this perception of value and use it to decide to purchase services offered by social enterprises. Consequently, one of the challenges that managers face is dealing with the social and economic values exchanged with their clients, while acting in accordance with their social mission and achieving what consumers appreciate and also what the company considers valuable in their business model. Third, every social enterprise needs to promote socially responsible consumption more actively and efficiently. To achieve this, greater efforts are required to transform the firm in a more sustainable one through business model innovation and consumer involvement to generate a more comprehensive and significant social and environmental impact. Our study showed that consumers see value in this proposition, facilitating satisfaction and loyalty.

Our research contributes to the understanding of business model innovation in social enterprises from two aspects. First, the role of an antecedent of perceptions of business model innovativeness such as socially responsible consumption suggests that social enterprises should consider these values when trying to provide timely and effective responses to the market they committed to serve. Second, the impact of the perception of value in the social business model directly on satisfaction and indirectly on customer loyalty indicates that it is an important variable to consider. Attention to these aspects can make a difference when social enterprises have the goals of surviving and achieving the expected social impact.

\section{References}

Achtenhagen, L., Melin, L., \& Naldi, L. (2013). Dynamics of business models-strategizing, critical capabilities and activities for sustained value creation. Long range planning, 46(6), 427-442. https://doi. org/10.1016/j.lrp.2013.04.002

Anderson, J. C., Rungtusanatham, M., \& Schroeder, R. G. (1994). A theory of quality management underlying the Deming management method. Academy of management Review, 19(3), 472-509. https://doi. org/10.5465/amr.1994.9412271808

Anderson, J. C., Narus, J. A., \& Van Rossum, W. (2006). Customer value propositions in business markets. Harvard Business Review, 84(3), 20-24.

Austin, J. E., \& Seitanidi, M. M. (2012). Collaborative value creation: A review of partnering between nonprofits and businesses: Part I. Value creation spectrum and collaboration stages. Nonprofit and voluntary sector quarterly, 41(5), 726-758. https://doi. org/10.1177/0899764012450777

Battilana, J., \& Lee, M. (2014). Advancing research on hybrid organizing-Insights from the study of social enterprises. Academy of Management Annals, 8(1), 397-441. https://doi.org/10.5465/19416520.2 014.893615

Berends, H., Smits, A., Reymen, I., \& Podoynitsyna, K. (2016). Learning while (re) configuring: Business model innovation processes in established firms. Strategic Organization, 14(3), 181-219. https://doi. org/10.1177/1476127016632758

Bereznoi, A. (2015). Business model innovation in corporate competitive strategy. Problems of Economic Transition, 57(8), 14-33. https:// doi.org/10.1080/10611991.2014.1042313 
Calonius, H. (2006). Contemporary research in marketing: a market behaviour framework. Marketing Theory, 6(4), 419-428. https://doi. org/10.1177/1470593106069936

Caruana, A. (2002). Service loyalty. European journal of marketing, 36(7/8), 811-828. https://doi.org/10.1108/03090560210430818

Chell, K., \& Mortimer, G. (2014). Investigating online recognition for blood donor retention: an experiential donor value approach. International Journal of Nonprofit and Voluntary Sector Marketing, 19(2), 143-163. https://doi.org/10.1002/nvsm.1489

Chesbrough, H., Lettl, C., \& Ritter, T. (2018). Value creation and value capture in open innovation. Journal of Product Innovation Management, 35(6), 930-938. https://doi.org/10.1111/jpim.12471

Clauss, T. (2017). Measuring business model innovation: conceptualization, scale development, and proof of performance. R\&D Management, 47(3), 385-403. https://doi.org/10.1111/radm.12186

Clauss, T., Kesting, T., \& Naskrent, J. (2018). A rolling stone gathers no moss: the effect of customers' perceived business model innovativeness on customer value co-creation behavior and customer satisfaction in the service sector. R\&D Management, 49(2), 180-203. https:// doi.org/10.1111/radm.12318

Clauss, T., Harengel, P., \& Hock, M. (2019). The perception of value of platform-based business models in the sharing economy: determining the drivers of user loyalty. Review of Managerial Science, 13(3), 605-634.

Crane, A. (2001). Unpacking the ethical product. Journal of Business Ethics, 30(4), 361-373. https://doi.org/10.1023/A:1010793013027

De Klerk, H. M., Kearns, M., \& Redwood, M. (2019). Controversial fashion, ethical concerns and environmentally significant behaviour. International Journal of Retail \& Distribution Management, 47(1), 1938. https://doi.org/10.1108/IJRDM-05-2017-0106

Durif, F., Boivin, C., Rajaobelina, L., \& François-Lecompte, A. (2011). Socially responsible consumers: profile and implications for marketing strategy. International Review of Business Research Papers, 7(6), 215-224.

Foss, N. J., \& Saebi, T. (2018). Business models and business model innovation: Between wicked and paradigmatic problems. Long Range Planning, 51(1), 9-21. https://doi.org/10.1016/j.lrp.2017.07.006

Fraering, M., \& Minor, M. S. (2013). Beyond loyalty: customer satisfaction, loyalty, and fortitude. Journal of Services Marketing, 27(4), 334-344. https://doi.org/10.1108/08876041311330807

Francois-Lecompte, A., \& Roberts, J. A. (2006). Developing a measure of socially responsible consumption in France. Marketing Management Journal, 16(2), 50-66.

Gallouj, F., \& Weinstein, O. (1997). Innovation in services. Research policy, 26(4-5), 537-556. https://doi.org/10.1016/S00487333(97)00030-9
Ge, J., Xu, H., \& Pellegrini, M. M. (2019). The effect of value cocreation on social enterprise growth: Moderating mechanism of environment dynamics. Sustainability, 11(1), 250-270. https://doi. org/10.3390/su11010250

George, G., \& Bock, A. J. (2011). The business model in practice and its implications for entrepreneurship research. Entrepreneurship theory and practice, 35(1), 83-111. https://doi.org/10.1111/j.15406520.2010.00424.x

Golob, U., Podnar, K., Koklič, M. K., \& Zabkar, V. (2019). The importance of corporate social responsibility for responsible consumption: Exploring moral motivations of consumers. Corporate Social Responsibility and Environmental Management, 26(2), 416-423. https://doi. org/10.1002/csr.1693

Gremler, D. D., \& Brown, S. W. (1999). The loyalty ripple effect. International Journal of Service Industry Management, 10(3), 271-293. https://doi.org/10.1108/09564239910276872

Gustafsson, A., Johnson, M. D., \& Roos, I. (2005). The effects of customer satisfaction, relationship commitment dimensions, and triggers on customer retention. Journal of marketing, 69(4), 210-218. https:// doi.org/10.1509/jmkg.2005.69.4.210

Karimi, J., \& Walter, Z. (2016). Corporate entrepreneurship, disruptive business model innovation adoption, and its performance: The case of the newspaper industry. Long Range Planning, 49(3), 342-360. https://doi.org/10.1016/j.lrp.2015.09.004

Keiningham, T., Aksoy, L., Bruce, H. L., Cadet, F., Clennell, N., Hodgkinson, I. R., \& Kearney, T. (2020). Customer experience driven business model innovation. Journal of Business Research, 116, 431-440. https://doi.org/10.1016/j.jbusres.2019.08.003

Kim, B., \& Lee, Y. (2020). Effects of perceived value and value congruence on loyalty about products or services provided by social enterprises: Focused on commitment and trust. Journal of Digital Convergence, 18(1), 83-92. https://doi.org/10.14400/ JDC.2020.18.1.083

Lee, I. (2015). A social enterprise business model for social entrepreneurs: theoretical foundations and model development. International Journal of Social Entrepreneurship and Innovation, 3(4), 269-301. https://doi.org/10.1504/IJSEI.2015.069351

Lindič, J., \& Marques da Silva, C. M. (2011). Value proposition as a catalyst for a customer focused innovation. Management Decision, 49(10), 1694-1708. https://doi.org/10.1108/00251741111183834

Lusch, R. F., \& Nambisan, S. (2015). Service innovation: A servicedominant logic perspective. MIS quarterly, 39(1), 155-176.

Lusch, R. F., Vargo, S. L., \& O’brien, M. (2007). Competing through service: Insights from service-dominant logic. Journal of retailing, 83(1), 5-18. https://doi.org/10.1016/j.jretai.2006.10.002 
Mahmoud, M. A., Hinson, R. E., \& Anim, P. A. (2018). Service innovation and customer satisfaction: the role of customer value creation. European Journal of Innovation Management, 21(3), 402-422. https:// doi.org/10.1108/EJIM-09-2017-0117

Markides, C. (2006). Disruptive innovation: In need of better theory. Journal of product innovation management, 23(1), 19-25. https://doi. org/10.1111/j.1540-5885.2005.00177.x

Moisescu, O. I. (2018). From perceptual corporate sustainability to customer loyalty: A multi-sectorial investigation in a developing country. Economic research-Ekonomska istraživanja, 31(1), 55-72. https:// doi.org/10.1080/1331677X.2017.1421998

Mook, L., Chan, A., \& Kershaw, D. (2015). Measuring social enterprise Value creation: The case of furniture bank. Nonprofit Management and Leadership, 26(2), 189-207. https://doi.org/10.1002/nml.21185

Nielsen, C., \& Bukh, P. N. (2011). What constitutes a Business Model: The perception of financial analysts. International Journal of Learning and Intellectual Capital, 8(3), 256-271. https://doi.org/10.1504/ IJLIC.2011.041072

Olofsson, S., Hoveskog, M., \& Halila, F. (2018). Journey and impact of business model innovation: The case of a social enterprise in the Scandinavian electricity retail market. Journal of cleaner production, 175, 70-81. https://doi.org/10.1016/j.jclepro.2017.11.081

Osterwalder, A., \& Pigneur, Y. (2010). Business model generation: a handbook for visionaries, game changers, and challengers. Hoboken/ NJ: Wiley \& Sons.

Petrovskaya, I., \& Haleem, F. (2020). Socially responsible consumption in Russia: Testing the theory of planned behavior and the moderating role of trust. Business Ethics: A European Review. Business Ethics: A European Review, 30(1), 38-53. https://doi.org/10.1111/ beer. 12322

Pitelis, C. N. (2009). The co-evolution of organizational value capture, value creation and sustainable advantage. Organization studies, 30(10), 1115-1139. https://doi.org/10.1177/0170840609346977

Reim, W., Sjödin, D., \& Parida, V. (2018). Mitigating adverse customer behaviour for product-service system provision: An agency theory perspective. Industrial Marketing Management, 74, 150-161. https://doi.org/10.1016/j.indmarman.2018.04.004

Roberts, J. A. (1993). Sex differences in socially responsible consumers' behavior. Psychological Reports, 73(1), 139-148. https://doi. org/10.2466/pr0.1993.73.1.139

Roberts, J. A. (1995). Profiling levels of socially responsible consumer behavior: a cluster analytic approach and its implications for marketing. Journal of marketing Theory and practice, 3(4), 97-117. https:// doi.org/10.1080/10696679.1995.11501709
Roberts, J. A. (1996). Will the real socially responsible consumer please step forward?. Business horizons, 39(1), 79-84.

Santos, F., Pache, A. C., \& Birkholz, C. (2015). Making hybrids work: Aligning business models and organizational design for social enterprises. California Management Review, 57(3), 36-58. https://doi. org/10.1525/cmr.2015.57.3.36

Severo, E. A., De Guimarães, J. C. F., \& Dellarmelin, M. L. (2021). Impact of the COVID-19 pandemic on environmental awareness, sustainable consumption and social responsibility: Evidence from generations in Brazil and Portugal. Journal of Cleaner Production, 286, 124947. https://doi.org/10.1016/j.jclepro.2020.124947

Sjödin, D., Parida, V., Jovanovic, M., \& Visnjic, I. (2020). Value creation and value capture alignment in business model innovation: A process view on outcome-based business models. Journal of Product Innovation Management, 37(2), 158-183. https://doi.org/10.1111/ jpim.12516

Skalén, P., Gummerus, J., Von Koskull, C., \& Magnusson, P. R. (2015). Exploring value propositions and service innovation: a service-dominant logic study. Journal of the Academy of Marketing Science, 43(2), 137-158. https://doi.org/10.1007/s11747-013-0365-2

Szymanski, D. M., \& Henard, D. H. (2001). Customer satisfaction: A meta-analysis of the empirical evidence. Journal of the academy of marketing science, 29(1), 16. https://doi.org/10.1177/0092070301291002

Teece, D. J. (2010). Business models, business strategy and innovation. Long range planning, 43(2-3), 172-194. https://doi.org/10.1016/j. lrp.2009.07.003

Wang, Z., \& Zhou, Y. (2020). Business model innovation, legitimacy and performance: social enterprises in China. Management Decision. In press. https://doi.org/10.1108/MD-05-2019-0678

Webb, D. J., Mohr, L. A., \& Harris, K. E. (2008). A re-examination of socially responsible consumption and its measurement. Journal of business research, 61(2), 91-98. https://doi.org/10.1016/j.jbusres.2007.05.007

West, S. G., Taylor, A. B., \& Wu, W. (2012). Model fit and model selection in structural equation modeling. R. H. Hoyle (Ed.). Handbook of structural equation modeling. (pp. 209-231). New York, NY: Guilford Press.

Woo, H., Kim, S. J., \& Wang, H. (2021). Understanding the role of service innovation behavior on business customer performance and loyalty. Industrial Marketing Management, 93, 41-51. https://doi. org/10.1016/j.indmarman.2020.12.011

Woodside, S. J. (2018). Dominant logics US WISEs and the tendency to favor a market-dominant or social mission-dominant approach. Social Enterprise Journal, 14(1), 39-59. https://doi.org/10.1108/SEJ01-2016-0001 
Woratschek, H., Horbel, C., \& Popp, B. (2020). Determining customer satisfaction and loyalty from a value co-creation perspective. The Service Industries Journal, 40(11-12), 777-799. https://doi.org/10.108 0/02642069.2019.1606213

YuSheng, K., \& Ibrahim, M. (2019). Service innovation, service delivery and customer satisfaction and loyalty in the banking sector of Ghana. International Journal of Bank Marketing, 37(5), 1215-1233. https://doi.org/10.1108/IJBM-06-2018-0142

Zainol, N., Zainol, F., Ibrahim, Y., \& Afthanorhan, A. (2019). Scaling up social innovation for sustainability: The roles of social enterprise capabilities. Management Science Letters, 9(3), 457-466. https://doi. org/ 10.5267/j.msl.2018.12.005
Zainuddin, N., Tam, L., \& McCosker, A. (2016). Serving yourself: value self-creation in health care service. Journal of Services Marketing, 30(6), 586-600.

Zhao, H. H., Gao, Q., Wu, Y. P., Wang, Y., \& Zhu, X. D. (2014). What affects green consumer behavior in China? A case study from Qingdao. Journal of Cleaner Production, 63, 143-151. https://doi. org/10.1016/j.jclepro.2013.05.021 